\title{
Application of Offshore HDPE Pipes Route Design in North Maluku Indonesia
}

\author{
Franto Novico ${ }^{1 *}$, Indra Kurniawan², Andi Egon 3,4 , Davide Merli5 \\ ${ }^{1}$ Marine Geological Research and Development Center, Ministry of Energy and Mineral Resources, \\ Republic of Indonesia \\ Jl. Dr. Djunjunan No.236, Husen Sastranegara, Bandung, Jawa Barat 40174, Indonesia \\ 2Directorat General of Water Resource, Ministry of Public Works and Housing, Republic of Indonesia \\ JL. Pattimura 20, Kebayoran Baru Jakarta,12110 Indonesia \\ ${ }^{3}$ Oceanography, Faculty of Earth Sciences and Technology, Bandung Institute of Technology, Indonesia \\ ${ }^{4}$ Civil Engineeering, College of Science and Engineering, National University of Ireland Galway, Ireland \\ ${ }^{5}$ Division of Hydraulics and Maritime Works, ENSER srl, Italy \\ Email: franto.novico@esdm.go.id
}

\begin{abstract}
The lack of fresh water for the inhabitants of Maitara island is a very urgent problem to be solved. Two main factors at least must be taken into account to deliberate the right of way of subsea High-density polyethylene (HDPE) pipes, namely the hydrodynamic conditions and of a block analysis. This paper presents the study to justify the best route of subsea HDPE pipes based on hydrodynamic model analysis and concrete block strategy. The method used to analyze the best route includes 2 aspects. Firstly, the investigation method consisting of a bathymetric survey conducted by a single beam echosounder, 15 days tidal observations and seabed sediment sampling. Secondly, the hydrodynamic modelling analysis using Mike 21 FMHD and concrete block analysis, all these studies have been completed in August 2018. In the morphological behaviour analysis, three alternative routes are considered for the subsea HDPE pipes from Tidore Island to Maitara Island. The outcome of the analysis shows that the second track line option has the smallest impact by the hydrodynamic conditions, with a current speed of less than $0,5 \mathrm{~m} / \mathrm{sec}$ and a significant wave height of fewer than 1.2 meters. Furthermore, the uniformity of the lithology along the route is the other reason to select the second route. Finally, the concrete block analysis generated a minimum dimension of $75 \mathrm{~cm} \times 60 \mathrm{~cm} \times 30 \mathrm{~cm}$, and a free span of 3 meters is safe to absorb the uplift and drag forces acting on the pipe.
\end{abstract}

Keywords: Application design, HDPE pipe, Hydrodynamic analysis, Concrete block strategy

\section{Introduction}

Maitara Island is part of the Halmahera Islands see Figure $1 \mathrm{~A}$, and it is situated between Tidore and Ternate Islands and administratively is part of subdistrict North Tidore, Tidore Kepulauan Municipality, North Maluku Province Indonesia see Figure 1B. The area of Tidore Island spreads $2.04 \mathrm{~km} 2$ (BPS, 2019) with a coastline of about $6,225 \mathrm{~km}$ and the population reaches 2,183 (BPS 2019). The rainfall of Tidore Kepulauan Municipality is in the range of $1,503.5 \mathrm{~mm}$ to $2,339 \mathrm{~mm}$ (BPS, 2020). The topography of Maitara consists of hills with a slope of $2 \%$ to $15 \%$ so the inhabitant lives in the coastal area with more gentle slopes and close access to the beach. Geologically, Maitara Island is a volcanic island nonetheless the volcanic activity does not exist anymore throughout the region. Based on Geological Systematic Map (Apandi and Sudana, 1980) it could be found that the lithological conditions around the route plan consist of two types of rock unit formations, the Holocene volcanic units $\mathrm{QHv}$ and the Alluvium Qa coastal deposit. The lithology of the Holocene volcanic unit QHv could be found in the Maitara Island and consists of andesite breccia, andesite-basalt lava and tuff while the coastal deposits Qa are located in the Tidore Island and contain clays, silt, sand and gravel. The offshore area between Maitara and Tidore Island is still identified as the Maluku Sea within 570m to more than $1.2 \mathrm{~km}$ width, see Figure $1 \mathrm{C}$. The marine transportation in Tidore Island is supported by the Port of Rum, where the berth operating ratio (BOR) of speed boat jetties reach $75 \%$, BOR of motorboats (small vessel) reaches $48 \%$ and the number of vessel visits reaches 47,052 (Sujarwanto, 2019) giving a good representation of the marine traffic in this area.

The issue of freshwater distribution has been investigated for few decades also in Europe (de Kok, 2002), Africa (Babah et al., 2012, 2015), Asia (Mu et al., 2015) and America (Rocha, 2018) but most studies were carried out on land and deltas. It is still rare to find water distribution among the islands since there are not many countries that have a lot of islands such as Indonesia. Due to the catchment and 
hydrogeology limitation thus, Maitara Island in fact can not receive enough precipitation to fill its demand. Therefore, the idea of distributing the water from the outside island has appeared. Considering the marine environments, simplicity and the limitation of budget, the idea to transport fresh water from Tidore to Maitara Island without a buried system has emerged. However, the scarcity of offshore water distribution studies forced us to research the application of laying the offshore HDPE pipes. However, the hydrodynamic impact due to currents and waves and also the uplift force must be reduced to stabilize the pipes. Therefore, this study aims to identify the best route of an offshore HDPE considering the hydrodynamic forces acting on the pipe. To achieve this goal, the hydrodynamic analysis and the anchor block design will be conducted to illustrate the pipe laying application.

\section{Materials and Methods}

\section{Acquisition data}

Single-Beam Echo Sounder (SBES) Teledyne Odom Hydrographic EchoTrac Sounder CV100 was applied to acquire bathymetry data. The accuracy of the bathymetry reaches less than $10 \mathrm{~cm}$. The positioning and heading were used by GNSS Veripos LD 4 and processing software by EIVA Navi Suites software. The positioning accuracy was less than $10 \mathrm{~cm}$ and the heading accuracy less than $1^{\circ}$. Besides, 15 days of tidal measurement from 14 July to 29 July 2018 has been conducted applying Valeport Tide Master S/N58971 and manual observations to correct the bathymetry and determine the design water level. The instrumentations for tidal measurement were placed in two locations, Tidore Island $\left(127^{\circ} 23^{\prime} 5.25^{\prime \prime} \mathrm{E}\right.$ and $\left.0^{\circ} 43^{\prime} 24.97^{\prime \prime} \mathrm{S}\right)$ and Maitara Island (127 $22^{\prime} 44.6^{\prime \prime} \mathrm{E}$, 044'6.25" S). Sampling seafloor sediments have been performed by the grab method for 24 samples along the routes, see Figure 3 . The grain size of sediment was defined according to the Unified Soil Classification System, American Standard Test Material ASTM D2487-06, 2006 to distinguish cohesive and non-cohesive sediments through megascopic in-situ analysis.

\section{Hydrodynamic models and concrete block analysis}

The loading on the pipe was assumed coming from both tidal current and significant wave effects for shallow and deep-water levels. Thus, the hydrodynamic analysis has been carried out using Mike 21 Flow model FM (DHI, 2012a) and Mike 21 Spectral Waves FM (DHI, 2012b). Forecasting the amplitude of current speed and wave height have been commonly used not only for the marine environment, such as in Novico et al. (2015) who gave evidence of the high amplitude of current speed in Sunda strait but also to analyze the marine energy in the straits such as in He et al. (2017), Atwater (2010). Furthermore, the wave and current forcing on the pipe body can be revealed such as Foda (1985),

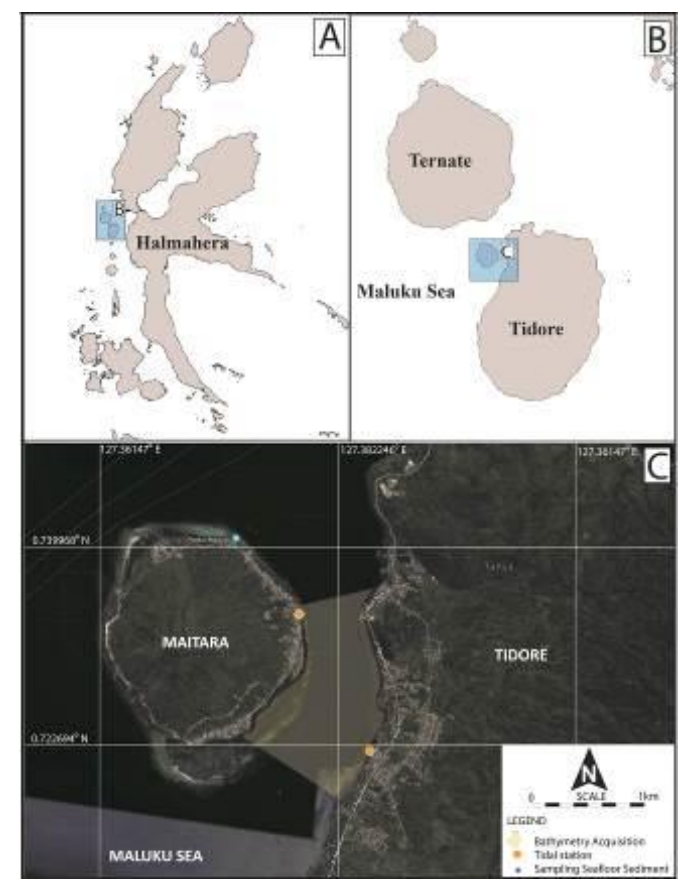

Figure 1. (A). The Maitara island is part of Halmahera Islands located in the western part of Halmahera Island. (B). As a remote area and positioned between Ternate and Tidore Islands, Maitara still has inhabitants (C). As the remote area and positioned between Ternate and Tidore Islands, Maitara still has inhabitants. 


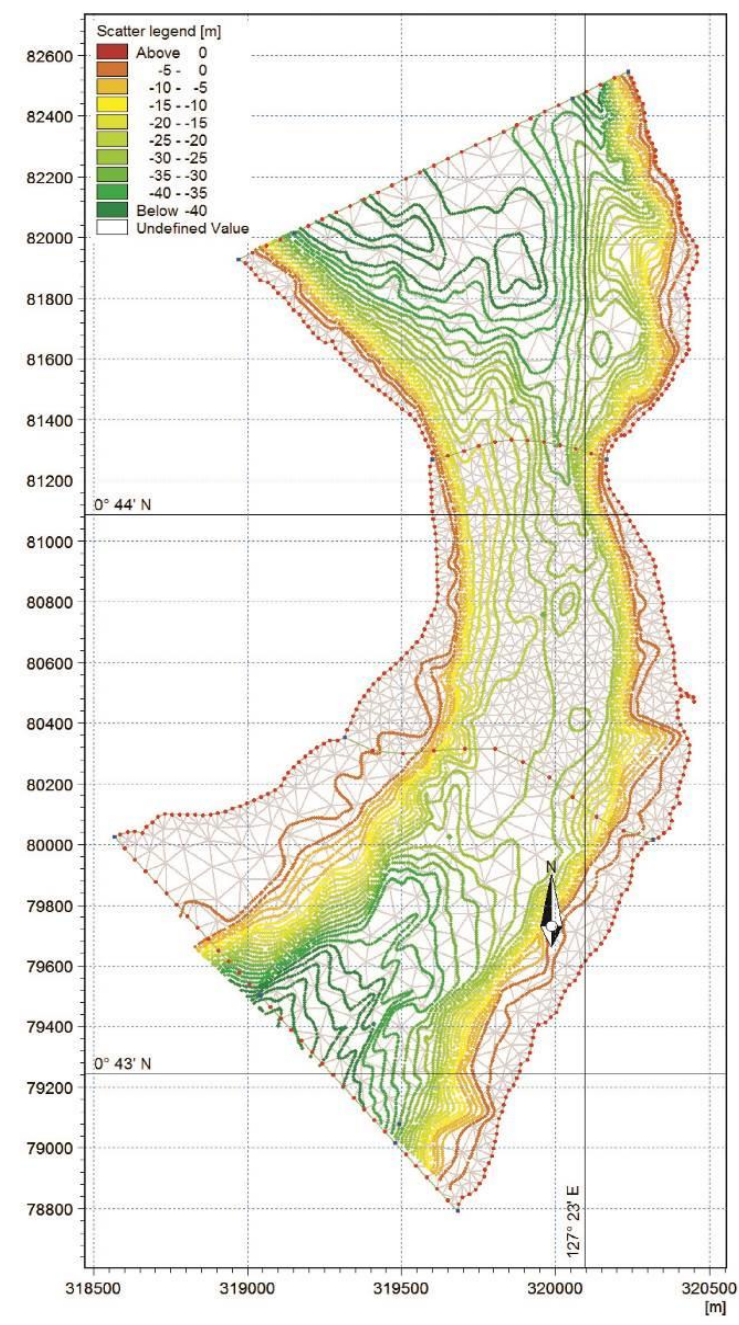

Figure 2. Model domain and mesh with bathymetry (depth in chart datum, a map projection is UTM 52N)

Foda et al (1990), Carneiro (2013). Thus, these allhydrodynamic conditions will be elaborated within Mike 21 to screen the smallest current and wave impacting laterally on the considered pipeline routes. The simulation is preceded by the creation of the model domain such as in Figure 2, and applying the bathymetry and tidal force to generate the open boundaries.

Since the HDPE pipes will be laid on the seafloor, concrete blocks will be designed to sustain hydrodynamic forces according to literature methods as well as International Standards (Det Norske Veritas DNV, 1988; 1993; 2013; 2017 and USACE, 2002). Besides, as an extreme design condition for the anchor block a flow current with 100 years return period is considered. No dataset of current velocity is available in this area, therefore the design flow velocity is derived by DNV $(1993,2013)$, and Hale et al. (1989), where both the current and wave load can be multiplied by a safety factor of 1.1 for a shallow area to 1.4 for middle strait. Furthermore, the same return period of 100 years should be considered for the design wave. The lack of data brings us to calculate the design wave using USACE (2002), an empirical method based on the longest fetch from the installation site assuming a wind speed of $30 \mathrm{~m} . \mathrm{s}^{-1}$ as a conservative approach.

\section{Results and Discussion}

\section{Seafloor condition}

Based on the survey campaign the morphology of the study area can be illustrated as shown in Figure 3. The shallow area situated in the middle with a water depth of less than $30 \mathrm{~m}$. The deepest area can be found in the north and the south of the study area reaching more than 50m. Concerning DNV (1993), this area could be classified from shallow to the deep sea. The Nearshore area at Maitara Island indicates the large distribution of the rocky bulge, coral reef and seagrass, which can be found in the southeast part of the island: red colour in Figure 3 symbolizes the shallow area where water depth is less than $4 \mathrm{~m}$. 


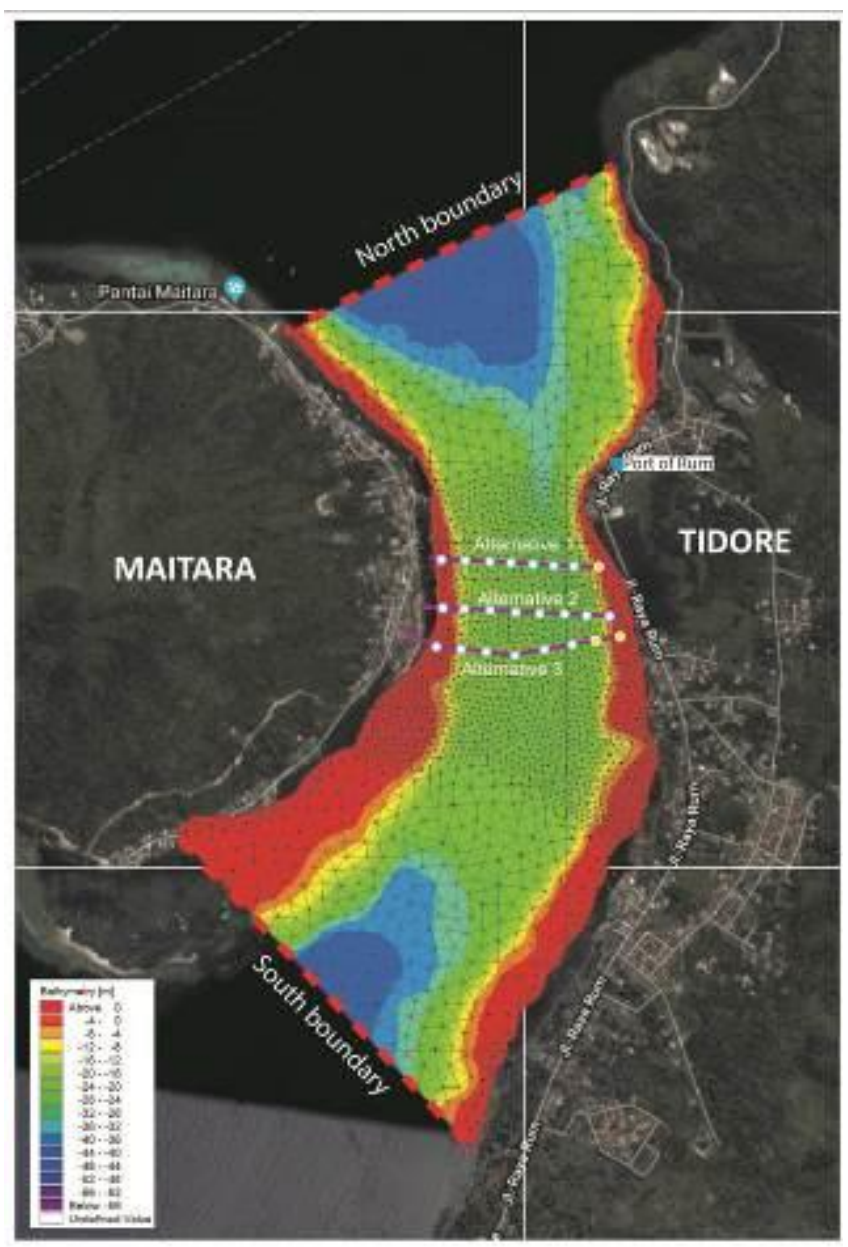

Figure 3. Bathymetry of the study area where the red color illustrates the shallow area and the blue color presents the deepest area. Purple lines are the proposed pipe routes along the strait and the white-yellow circle is the sampling sediment locations. The blue dot represents the port of Rum.

Based on grain size distribution analysis of 24 samples collected in-situ along the 3 alternative routes, it can be concluded that the seabed is covered by non-cohesive sediment (dominantly coarse sand) and reefal-rocky environment, as illustrated by the white circles along the routes in Figure 3 . There are only 3 samples that contain cohesive sediment, namely greyish brown silt, discovered at the eastern part of the alternative 1 and 3 as represented by the yellow circles in Figure 3 . Thus, due to the seafloor lithology, the second route is selected since it has a uniformity of grain size.

\section{Pipe and route selection}

The pipe category has been selected as HDPE PN20 within $110 \mathrm{~mm}$ diameter. Design pipe density is $4.35 \mathrm{~kg} \cdot \mathrm{m}^{-3}$ with a minimum pipe thickness of $15.1 \mathrm{~mm}$. Three alternatives for the route have been evaluated by considering the length, morphology and seafloor condition, Figure 3 . The lengths of the routes are, from North to South: $613 \mathrm{~m}, 736 \mathrm{~m}, 858 \mathrm{~m}$, as shown in Figure 4. Furthermore, the routes also consider the marine traffic around the area due to the presence of Rum Port in Tidore, consequently, a more distant route from the port is better to minimize the risks. Three cross-sections for each route can be seen in Figure 4, which illustrates the morphology along the routes. Furthermore, as highlighted by the vertical exaggeration in Figure 4, the first alternative has slopes in the range of $43.77 \%$ to $53.80 \%$, the second route has slopes in the range $41.99 \%$ to $51.92 \%$, the third route has slopes in the range $26.88 \%$ to $32.80 \%$. This circumstance leads to choose the second route as the best route to be further calculated.

\section{Tidal data}

Two tidal stations have been constructed at Maitara and Tidore Islands and the data was collected for 15 days, see Figure 5. The figure illustrates the raw data of the water elevation in the area of interest. The red line in the figure represents 

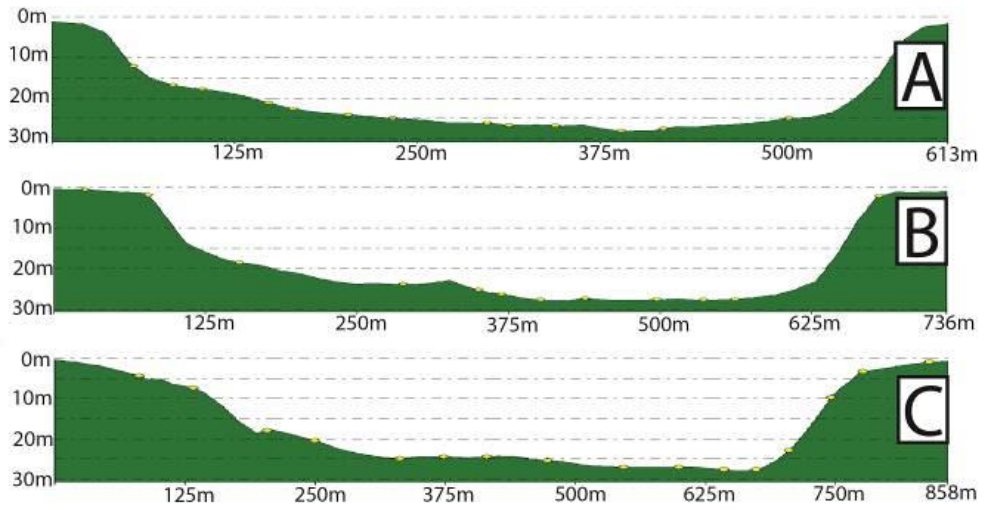

Figure 4. Morphology along pipe routes. A is the morphology along the first route located in the northern part of the strait. B is the morphology of the second route and $\mathrm{C}$ is the third route situated in the southern part of the strait.

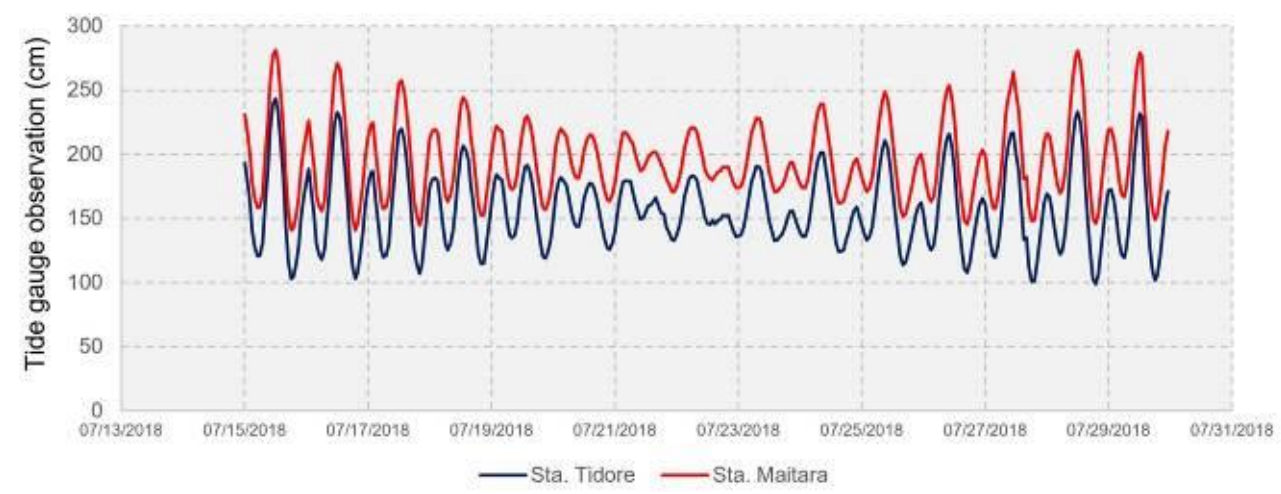

Figure 5. Raw data of tidal fluctuation for both Maitara and Tidore stations

Table 1. Main components of tidal at two stations

\begin{tabular}{cccccccccccc}
\hline \multirow{2}{*}{ Location } & \multicolumn{10}{c}{ Tidal Harmonic Component } & \multicolumn{10}{c}{$c$} \\
\cline { 2 - 11 } & & $\mathrm{So}$ & $\mathrm{M}_{2}$ & $\mathrm{~S}_{2}$ & $\mathrm{~N}_{2}$ & $\mathrm{~K}_{1}$ & $\mathrm{O}_{1}$ & $\mathrm{M}_{4}$ & $\mathrm{MS}_{4}$ & $\mathrm{~K}_{2}$ & $\mathrm{P}_{1}$ \\
\hline \multirow{2}{*}{ Maitara } & $\mathrm{A}(\mathrm{cm})$ & 196.11 & 11.29 & 22.48 & 11.55 & 21.01 & 13.86 & 1.12 & 1.54 & 6.07 & 6.93 \\
\multirow{3}{*}{ Tidore } & $\mathrm{g}\left({ }^{\circ}\right)$ & & 95.40 & 344.77 & 225.03 & 336.13 & 36.60 & 178.80 & 5.17 & 344.77 & 336.13 \\
& $\mathrm{~A}(\mathrm{~cm})$ & 156.75 & 11.30 & 22.41 & 11.54 & 21.20 & 13.89 & 1.18 & 1.48 & 6.05 & 7.00 \\
& $\mathrm{~g}\left({ }^{\circ}\right)$ & & 95.40 & 344.77 & 225.03 & 335.13 & 34.60 & 183.80 & 2.17 & 344.77 & 335.13 \\
\hline
\end{tabular}

the water fluctuation data in Maitara Island and the blue line represent the water elevation in Tidore Island, The two measurements show a similar pattern. By applying the admiralty method thus, the harmonic components of tidal can be revealed as can be perceived in Table 1. From both datasets, it can be concluded that the main tidal component has the same values such as M2, S2, K1 and 01 . Furthermore, using those parameters so the formzhal number can be calculated, (Thurman, 1994; Ross, 1995; Sumich, 1996). Value for the formzhal number 1.03 and 1.04 for Maitara station and Tidore station are found respectively. This means that the local tide can be classified as mixed semidiurnal, with two floods and two ebbs each day.

\section{Hydrodynamic models}

The simulation models have been implemented with the domain including Tidore and Maitara offshore area, Figure 3. Bathymetry field data were applied in the domain and the open boundary condition generated was the tidal fluctuation from Tide Model Driver (TMD) (Padman, 2005). Furthermore, the verification model as the foremost step to simulate the forecasting or hindcasting was conducted within the study. In this stage, the best simulation was identified and water elevation data were extracted then compared with the field observations data. The verification level of both 
ILMU KELAUTAN: Indonesian Journal of Marine Sciences March 2021 Vol 26(1):45-56

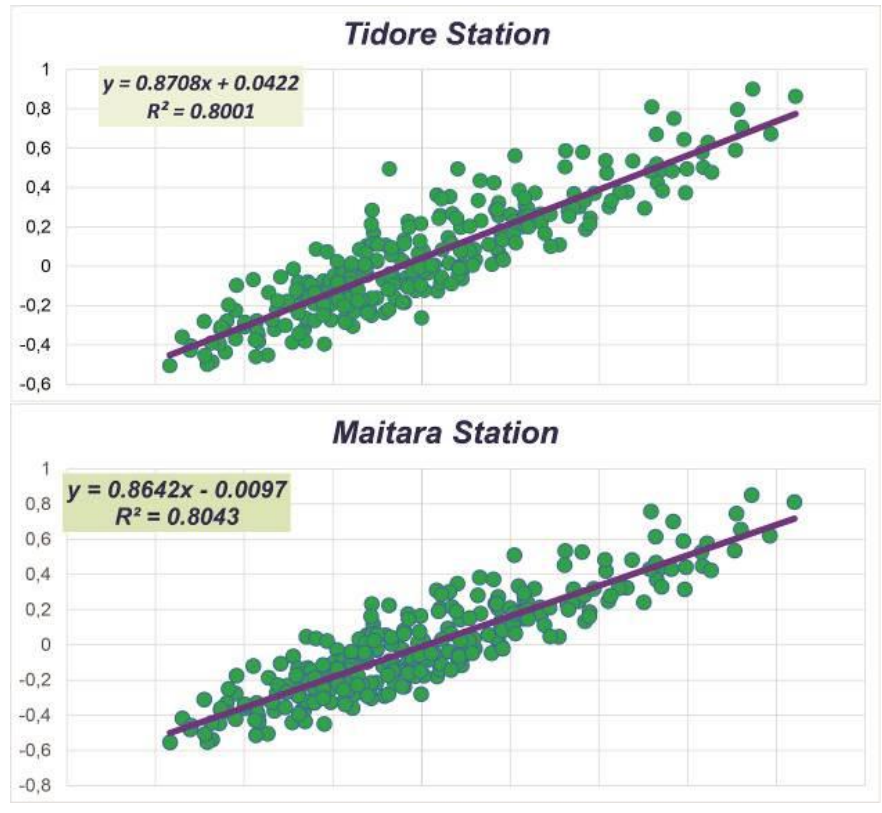

Figure 6. Model verification results for both Maitara station and Tidore station.

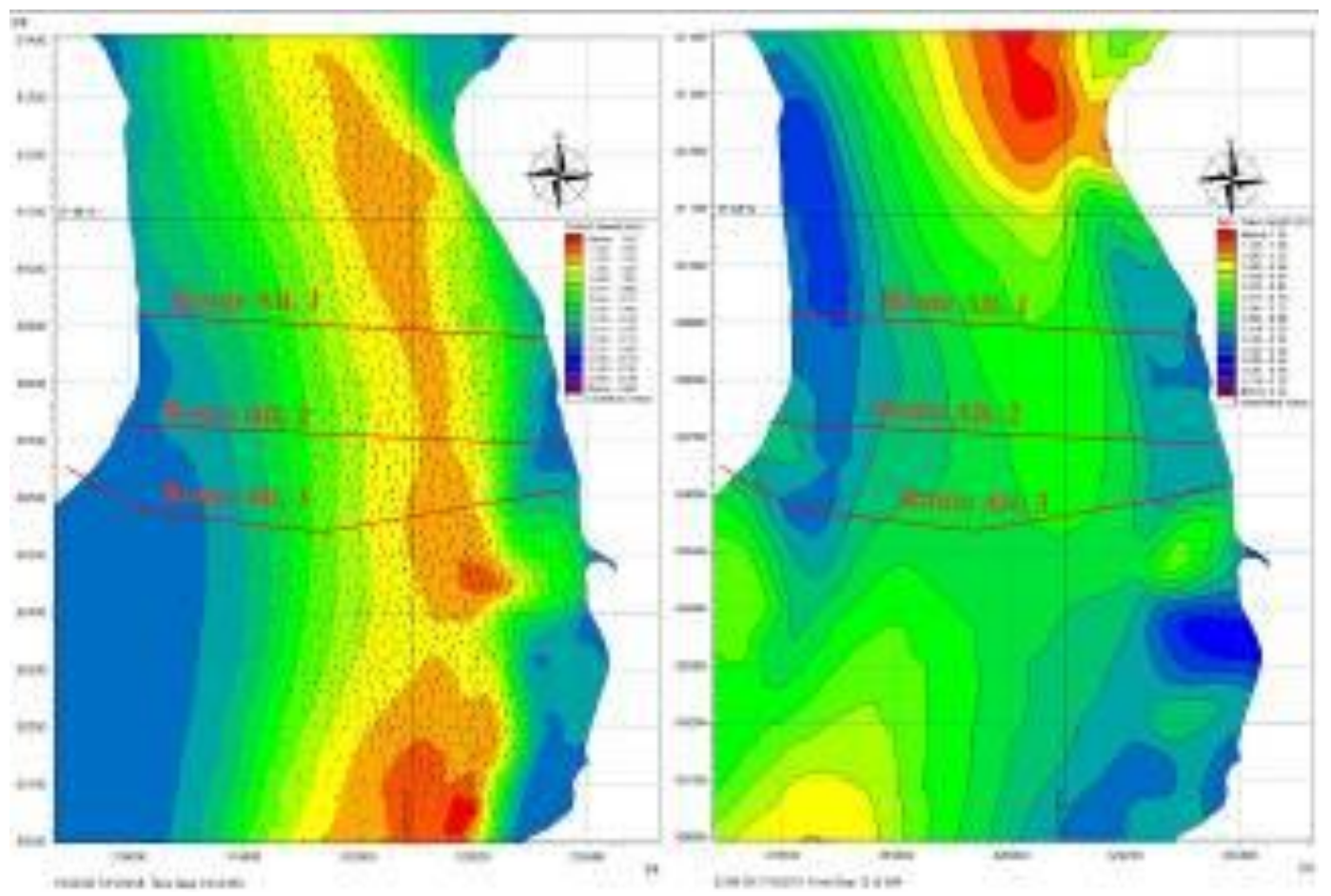

Figure 7. Snapshot of maximum current speed and significant wave height based on the hydrodynamic simulation result.

Table 2. Hydrodynamic results

\begin{tabular}{ccccccc}
\hline & \multicolumn{3}{c}{ Simulation Model } & \multicolumn{3}{c}{ Wave height significant $\mathrm{H}_{\text {sig }}(\mathrm{m})$} \\
\hline \multirow{2}{*}{ Route } & Max & Current speed $\left(\mathrm{m}^{-1} \mathrm{~s}^{-1}\right)$ & & Max & Average & Min \\
\cline { 2 - 7 } & 1.27 & 0.60 & 0.03 & 0.73 & 0.69 & 0.54 \\
2 & 1.25 & 0.57 & 0.03 & 0.70 & 0.67 & 0.55 \\
3 & 1.41 & 0.76 & 0.02 & 0.83 & 0.79 & 0.69 \\
\hline
\end{tabular}


ILMU KELAUTAN: Indonesian Journal of Marine Sciences March 2021 Vol 26(1):45-56

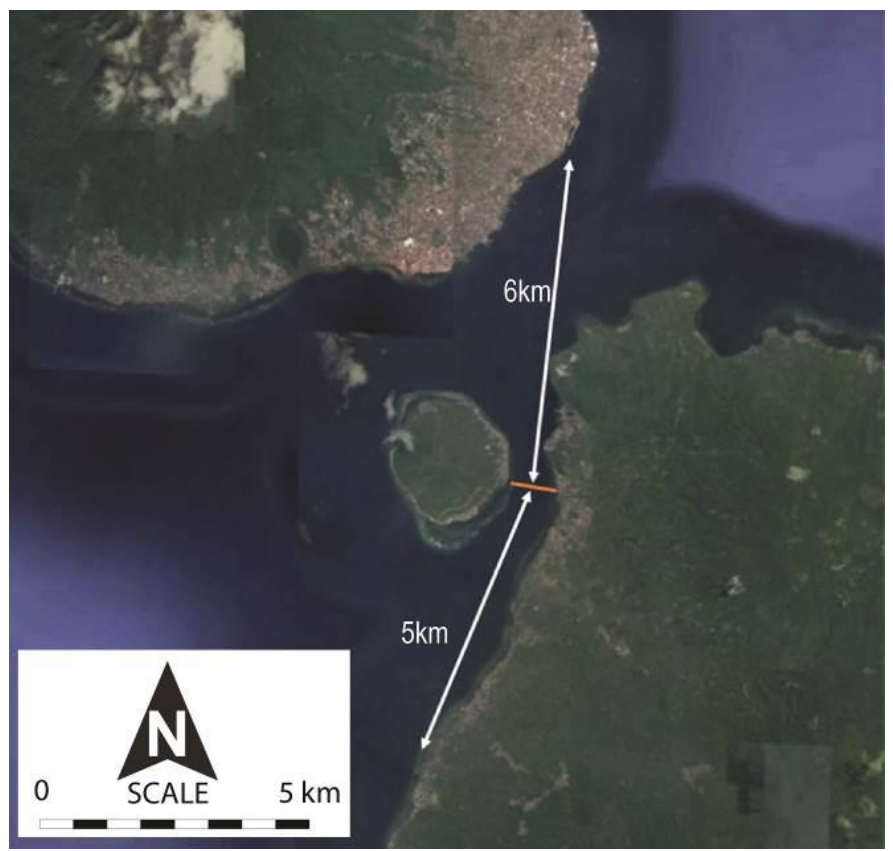

Figure 8. Fetch around offshore HDPE pipe routes
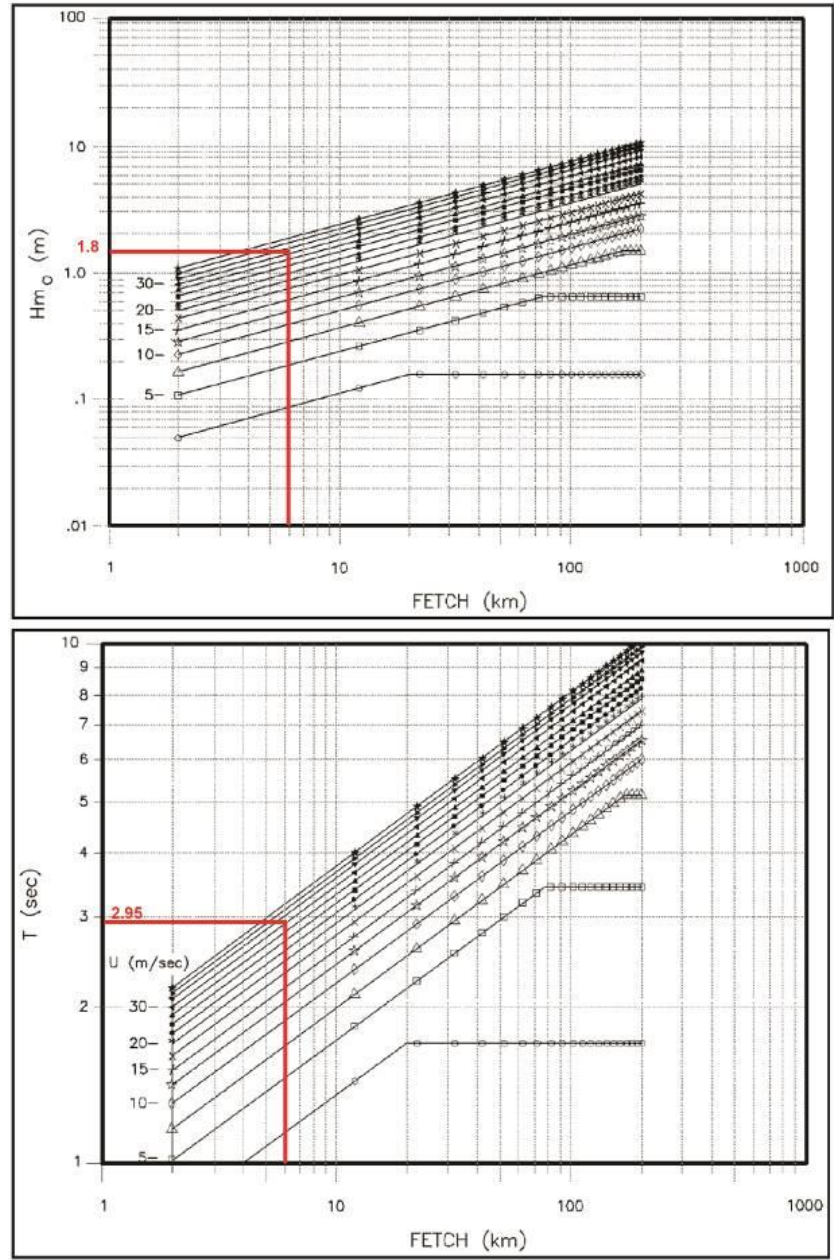

Figure 9. Estimation of wave height significant and period (Modified USACE, 2002) 
stations shows a high confidence level with a correlation factor of about $80 \%$, Figure 6 .

Furthermore, the selected simulation model will be used to analyze the hydrodynamic conditions along alternative routes. Both current speed and significant wave height are extracted laterally for each route to harvest the evidence of maximum hydrodynamic parameters. The highest current speed occurs at spring tide and reaches more than 1.5 m.s.-1 at a location in the southern part of the study area, Figure 7. However, the current speed along the routes indicates values generally less than $1.5 \mathrm{~m} . \mathrm{s}^{-1}$, Table 2. Besides, the maximum significant wave height is defined at the he northern part of the simulation domain as $1.08 \mathrm{~m}$, Figure 7 , while the highest value along the routes was less than $0.9 \mathrm{~m}$, Table 2 .

\section{HDPE pipe design}

Pipe selection of HDPE PN20 has been considered to avoid corrosion, (Hunt et al., 2017), degradation, Da Costa et al. (2018) and contamination, Arias-Villamizar and Vázquez-Morillas (2018), and also the pipe availability. Based on hydrodynamic analysis results and selected type of HDPE PN20 pipe the safety of the proposed design can be analyzed. The stability against hydrodynamic loads, namely currents (Hale et al., 1989) and waves (Cheng et al., 2016) will be verified, including concrete block analysis.

\section{Hydrodynamic analysis}

Regarding DNV, 2013, for submarine pipeline systems standard the offshore current must be calculated in the design against a return period of at least 100 years. For this purpose, it should be conducted an extreme value analysis of offshore flow velocity by using at least 10 years of field data. Due to the lack of measurements, this parameter will be multiplied by a safety factor of $\mathbf{1 . 4}$ for narrow strait (middle part) and 1.1 according to common practice for design (DNV, 1993; 1998; 2013).

A similar analysis must be done for the waves since an extreme value analysis with 100 years return period must be considered. Since the data availability is not sufficient the wave height can be calculated by using USACE (2002) which is an empirical method base on the longest fetch from the site, assuming a wind speed of $30 \mathrm{~m} . \mathrm{s}^{-1}$ as a conservative approach. Based on this method, the estimated wave height and wave period can be obtained. By applying $30 \mathrm{~m} . \mathrm{s}^{-1}$ of wind speed and $6 \mathrm{~km}$ of fetch, Figure 8 , the significant wave height can be defined as $1.8 \mathrm{~m}$ and the period is $3 \mathrm{sec}$, Figure 9.

\section{Offshore HDPE pipe specifications}

Since an offshore HDPE pipe, PN20 will be used to distribute the freshwater, specifications for the pipe will refer to DNV (2013). HDPE pipes are in general resistant against environmental degradation, chemical impacts and abrasion-resistant, nonetheless, the HDPE pipe PN20 still must follow the standard of a minimum of pipe thickness, Table 4. Referring to the HDPE PN20 specification, Table 5 this pipe must fulfil the requirement of $12 \mathrm{~mm}$ minimum thickness from DNV (2013) standard.

\section{Force acting on pipes}

The stability of the HDPE pipe can be analyzed by calculating both vertical and horizontal forces acting on the pipe. The inertia force $(\mathrm{FI})$ and the drag

Table 3. Hydrodynamic parameters

\begin{tabular}{lcc}
\hline Parameter & Formula & Magnitude \\
\hline $\begin{array}{l}\text { Wave period } \\
\text { Shallow water wave } \\
\text { current }\end{array}$ & Figure 9 & $3 \mathrm{~s}$ \\
$\begin{array}{l}\text { Shallow water } \\
\text { wavelength }\end{array}$ & $\sqrt{g H}$ & $2.62{\mathrm{~m} . \mathrm{s}^{-1}}^{-}$ \\
$\begin{array}{l}\text { Deepwater wave } \\
\text { current }\end{array}$ & $\sqrt{g H} T$ & $7.86 \mathrm{~m}$ \\
$\begin{array}{l}\text { Deepwater } \\
\text { wavelength }\end{array}$ & $\sqrt{g L / 2 \pi}$ & $4.68{\mathrm{~m} . \mathrm{s}^{-1}}^{2}$ \\
\hline
\end{tabular}

Table 4. Selected parameters and categories for offshore HDPE pipe

\begin{tabular}{|c|c|c|}
\hline Parameter & Category & Description \\
\hline Safety Class & Low & $\begin{array}{l}\text { Where failure implies a low } \\
\text { risk of human injury and } \\
\text { minor environmental and } \\
\text { economic consequences. }\end{array}$ \\
\hline $\begin{array}{l}\text { Classification } \\
\text { of Fluid }\end{array}$ & A & $\begin{array}{l}\text { Typical non-flammable } \\
\text { water-based fluids. }\end{array}$ \\
\hline $\begin{array}{l}\text { Classification } \\
\text { of Location }\end{array}$ & 2 & $\begin{array}{l}\text { The part of the } \\
\text { pipeline/riser in the near } \\
\text { platform (manned) area or } \\
\text { in areas with frequent } \\
\text { human activity. The extent } \\
\text { of location class } 2 \text { should } \\
\text { be based on appropriate } \\
\text { risk analyses. If no such } \\
\text { analyses are performed a } \\
\text { minimum horizontal } \\
\text { distance of } 500 \text { m shall be } \\
\text { adopted. }\end{array}$ \\
\hline $\begin{array}{l}\text { Minimum } \\
\text { pipe } \\
\text { thickness } \\
\text { requirement }\end{array}$ & $\begin{array}{l}\text { Minimum } \\
\text { protection } \\
\text { other ext } \\
\text { corrosion } \\
\text { For diame } \\
\text { minimum } \\
\text { shall be } \\
\text { above con }\end{array}$ & $\begin{array}{l}12 \mathrm{~mm} \text { unless equivalent } \\
\text { against accidental loads, } \\
\text { ernal loads and excessive } \\
\text { are provided by other means. } \\
\text { ters, less than } 219 \text { mm ( } 8 \text { ") } \\
\text { wall thickness can be less but } \\
\text { determined including the } \\
\text { siderations. }\end{array}$ \\
\hline
\end{tabular}



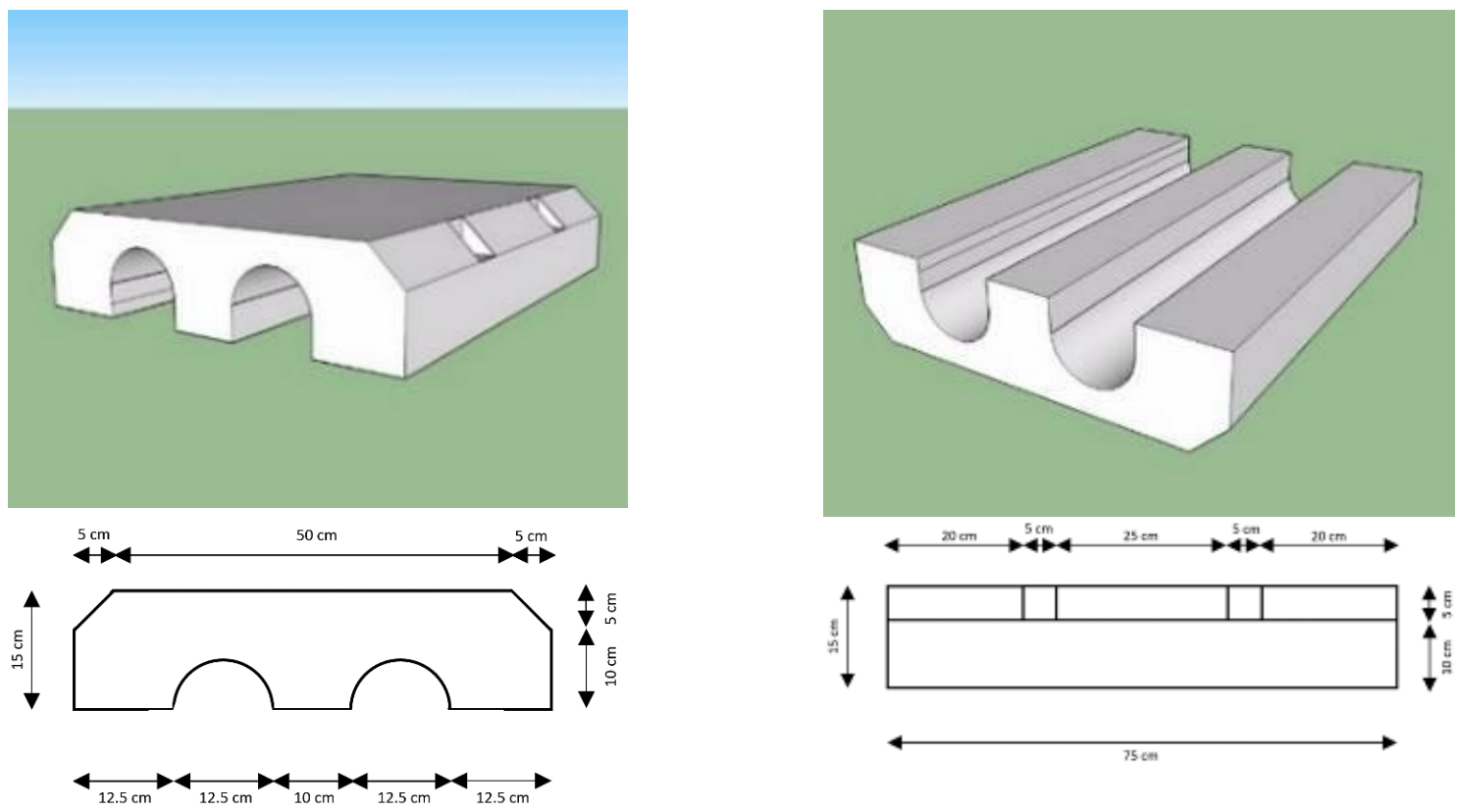

Figure 10. Concrete block design for two HDPE PN20 pipes which has a dimension of $50 \mathrm{~cm} \times 75 \mathrm{~cm} \times 30 \mathrm{~cm}$.

force (FD) are working in a vertical direction and lifting forces (FL) works in a lateral direction. The lifting force can affect pipe stability since it will reduce the weight of the pipe. In this study, the force acting on the pipes was calculated by DNV classification, DNV (2017; 2013; 1988; 1981). Furthermore, the on-bottom stability design of submarine pipelines is dealt with in much more detail on DNV (1988) and the hydrodynamic interaction is conducted using a Morrison formula (Trechet, 2004). Since the routes are located on shallow and deep water, so the hydrodynamic analysis takes into account both these conditions. In this case, deep water is defined by a water depth of more than 8 meters which correspond to the criteria of a ratio smaller than 0.5 between water depth and wavelength. The results of the hydrodynamic calculations are described in Table 6 and Table 7.

\section{Concrete block design}

The concrete block will be constructed to eliminate the hydrodynamic forces acting on the pipes. Therefore, the design standard such as DNV, 1988; 2017 will be applied to calculate the length of the span between the blocks and a sufficient total weight of the concrete block. The geometric design of the blocks is proposed in Figure 10. This design illustrates the double pipes within the concrete block and locked by bolts for each side. Based on Table 6 and Table 7 thus the weight of concrete block design (Ws) is such that it must compensate the distributed forces acting on pipe. For that reason, the design of
Table 5. Selected HDPE pipe specification

\begin{tabular}{lc}
\hline Pipe Class & PN 20 \\
\hline Pipe Diameter & $110 \mathrm{~mm}$ \\
Maximum pipe thickness & $15.95 \mathrm{~mm}$ \\
Minimum pipe thickness & $15.1 \mathrm{~mm}$ \\
Density & $4.35 \mathrm{~kg} \cdot \mathrm{m}-3$ \\
\hline
\end{tabular}

Table 6. Data input and hydrodynamic calculation for shallow water

\begin{tabular}{|c|c|c|}
\hline Parameter & Symbol & Magnitude \\
\hline \multicolumn{3}{|l|}{ Data Input } \\
\hline Pipe diameter (m) & $\mathrm{D}$ & 0.11 \\
\hline $\begin{array}{l}\text { The magnitude of offshore } \\
\text { current }\left(\mathrm{m}_{\mathrm{s}}^{-1}\right)\end{array}$ & $U_{c}$ & 1.375 \\
\hline $\begin{array}{l}\text { The velocity of wave significant } \\
\left(\mathrm{m} . \mathrm{s}^{-1}\right)\end{array}$ & Us & 0.42 \\
\hline Fluid density (kg.m-³) & $\rho$ & 1025 \\
\hline Wave phase angle (kg.m-3) & $\theta$ & 0 \\
\hline $\begin{array}{l}\text { Water horizontal effective } \\
\text { particle acceleration (m.s-2) }\end{array}$ & As & 0.88 \\
\hline Coefficient of hydrodynamic inert & $\mathrm{C}_{\mathrm{M}}$ & 3.29 \\
\hline Drag coefficient & $C_{D}$ & 0.7 \\
\hline Uplift coefficient & $\mathrm{CL}_{\mathrm{L}}$ & 0.9 \\
\hline Pipe-soil friction coefficient & $\mu$ & 0.7 \\
\hline Pipe stability calibration factor & $\mathrm{FW}_{W}$ & 1.1 \\
\hline \multicolumn{3}{|c|}{ Calculation analysis (each pipe) } \\
\hline $\begin{array}{l}\text { Inertia force per unit length } \\
(\mathrm{N} / \mathrm{m})\end{array}$ & $\mathrm{F}_{1}$ & 28.05 \\
\hline Drag force (N.m-1) & $\mathrm{F}_{\mathrm{D}}$ & 126.85 \\
\hline Lift force $\left(N \cdot \mathrm{m}^{-1}\right)$ & $\mathrm{FL}_{\mathrm{L}}$ & 163.09 \\
\hline Pipe weight force $\left(\mathrm{N} \cdot \mathrm{m}^{-1}\right)$ & Ws & 486.47 \\
\hline
\end{tabular}


ILMU KELAUTAN: Indonesian Journal of Marine Sciences March 2021 Vol 26(1):45-56

Table 7. Data input and hydrodynamic calculation for deep-water (>8m)

\begin{tabular}{|c|c|c|}
\hline Parameter & Symbol & Magnitude \\
\hline \multicolumn{3}{|c|}{ Data Input } \\
\hline Pipe diameter (m) & $\mathrm{D}$ & 0.11 \\
\hline The magnitude of offshore current $\left(\mathrm{m} . \mathrm{s}^{-1}\right)$ & $U_{c}$ & 1.75 \\
\hline The velocity of wave significant $\left(m \cdot \mathrm{s}^{-1}\right)$ & Us & 0.05 \\
\hline Fluid density (kg.m-3) & $\rho$ & 1025 \\
\hline Wave phase angle (kg.m-3) & $\theta$ & 0 \\
\hline Water horizontal effective particle acceleration (m.s-2) & As & 0.10 \\
\hline Coefficient of hydrodynamic inertia & $\mathrm{C}_{\mathrm{M}}$ & 3.29 \\
\hline Drag coefficient & $\mathrm{CD}_{\mathrm{D}}$ & 0.7 \\
\hline Uplift coefficient & $C_{L}$ & 0.9 \\
\hline Pipe-soil friction coefficient & $\mu$ & 0.7 \\
\hline Pipe stability calibration factor & $\mathrm{FW}_{\mathrm{W}}$ & 1.1 \\
\hline \multicolumn{3}{|c|}{ Calculation analysis (each pipe) } \\
\hline Inertia force per unit length (N.m-1) & $\mathrm{F}_{1}$ & 3.14 \\
\hline Drag force (N.m-1) & $\mathrm{F}_{\mathrm{D}}$ & 127.41 \\
\hline Lift force $\left(\mathrm{N} . \mathrm{m}^{-1}\right)$ & $F_{L}$ & 163.81 \\
\hline Pipe weight force $\left(\mathrm{N}^{\mathrm{m}} \mathrm{m}^{-1}\right)$ & $\mathrm{W}_{\mathrm{s}}$ & 461.09 \\
\hline
\end{tabular}

Table 8. Checking block design for shallow water

\begin{tabular}{|c|c|c|}
\hline Parameter & Symbol & Magnitude \\
\hline \multicolumn{3}{|c|}{ Pipe design for 1 lane per meter } \\
\hline Water volume in pipe per meter $(m-3)$ & $V_{w}$ & 0.0095 \\
\hline Water weight in pipe per meter $\left(\mathrm{N} \cdot \mathrm{m}^{-1}\right)$ & $\mathrm{F}_{\mathrm{w}}$ & 95.56 \\
\hline Pipe weight per meter (kg.m-1) & & 4.35 \\
\hline Force pipe weight per meter $\left(\mathrm{N}^{-\mathrm{m}^{-1}}\right)$ & $\mathrm{Fp}$ & 42.67 \\
\hline Total weight required $\left(\mathrm{N} \cdot \mathrm{m}^{-1}\right)=\mathrm{W}_{\mathrm{S}}-\mathrm{F}_{\mathrm{W}}-\mathrm{F}_{\mathrm{P}}$ & & 348.24 \\
\hline \multicolumn{3}{|c|}{ Block design for 2 pipes per 3 meters } \\
\hline Total block weight required for 2 lanes (N. $\left.\mathrm{m}^{-1}\right)$ & $W_{\text {req }}$ & 2089.43 \\
\hline Length of the block $(\mathrm{m})$ & & 0.75 \\
\hline Width of the block $(\mathrm{m})$ & & 0.50 \\
\hline Height of block (m) & & 0.30 \\
\hline Gross volume of the block $\left(\mathrm{m}^{3}\right)$ & & 0.1125 \\
\hline Net volume of the block $\left(\mathrm{m}^{3}\right)$ & & 0.0935 \\
\hline Concrete block density (kg. $\mathrm{m}^{-3}$ ) & $\rho$ & 2400 \\
\hline Total weight of concrete block (N.m-1) & $W_{\text {des }}$ & 2201.21 \\
\hline
\end{tabular}

Table 9. Checking block design for deep-water (>8m)

\begin{tabular}{|c|c|c|}
\hline Parameter & Symbol & Magnitude \\
\hline \multicolumn{3}{|c|}{ Pipe design for 1 lane per meter } \\
\hline Water volume in pipe per meter $\left(\mathrm{m}^{3}\right)$ & $V_{w}$ & 0.0095 \\
\hline Water weight in pipe per meter $\left(\mathrm{N} \cdot \mathrm{m}^{-1}\right)$ & Fw & 95.56 \\
\hline Pipe weight per meter (kg.m-1) & & 4.35 \\
\hline Force pipe weight per meter (N.m-1) & $\mathrm{Fp}_{\mathrm{p}}$ & 42.67 \\
\hline Total weight required $(\mathrm{N} / \mathrm{m})=\mathrm{W}_{\mathrm{S}}-\mathrm{F}_{\mathrm{W}}-\mathrm{F}_{\mathrm{P}}$ & & 322.86 \\
\hline \multicolumn{3}{|c|}{ Block design for 2 pipes per 3 meters } \\
\hline Total block weight required for 2 lanes (N. $\left.\mathrm{m}^{-1}\right)$ & $\mathrm{W}_{\text {req }}$ & 1937.17 \\
\hline Length of the block $(\mathrm{m})$ & & 0.75 \\
\hline Width of the block $(\mathrm{m})$ & & 0.50 \\
\hline Height of block (m) & & 0.30 \\
\hline Gross volume of the block $\left(\mathrm{m}^{3}\right)$ & & 0.1125 \\
\hline Net volume of the block $\left(\mathrm{m}^{3}\right)$ & & 0.0935 \\
\hline Concrete block density (kg.m-3) & $\rho$ & 2400 \\
\hline Total weight of concrete block (N.m-1) & $W_{\text {des }}$ & 2201.21 \\
\hline
\end{tabular}


concrete block for each meter per lane can be done regarding DNV (2017). Furthermore, that reference is used to calculate the free span between the concrete blocks. Due to the safety and small dynamics amplification of the subsea pipe, the ratio between free span and pipe diameter must be less than 30 $(L / D<30)$. Since the pipe diameter of HDPE PN20 is $110 \mathrm{~mm}$, the maximum free span allowed is 3.3 meters, and in this case, a span of 3 meters will be applied, and the concrete block design can be considered as shown in Table 8 and Table 9.

\section{Conclusion}

According to this study, the lateral and vertical forces of seawater acting on the HDPE PN20 subsea pipe especially the second route can be sustained due to the on-bottom stability of the subsea pipe. Besides, the freshwater fluctuation within the pipe also can be predicted and calculated to eliminate the force working in the pipe. The analysis of results from the model simulation confirmed that the hydrodynamic forces along the pipe do not occur equally along the pipe route. The higher magnitude of the tidal current and the significant wave high arises in the eastern part near Tidore Island where the water is deeper, with the lithology shows a softer seabed than in the western part. Nevertheless, the free span between concrete blocks and the concrete block weight itself has been shown to stabilize pipes against acting forces along the pipe. Therefore, these results constitute significant evidence to be considered as a model within the application design of the offshore pipe submission.

\section{Acknowledgement}

This study is fully supported by the Ministry of Public Works and Housing, Directorate General of Water Resources, the Republic of Indonesia. The field activities are granted by contract number No. KU.08.08/ATAB/PJPA-MU/06/2018. The authors also thank all team and local government of North Maluku Province and Maitara-Tidore people.

\section{References}

Apandi, T. \& Sudana, D. 1980. Geologic map of the Ternate quadrangle, North Maluku, Pusat Penelitian dan Pengembangan Geologi, Bandung, Badan Penelitian dan Pengembangan Energi dan Sumberdaya Mineral, Departemen Energi dan Suberdaya Mineral. Internal report, 1p.

Arias-Villamizar, C.A. \& Vázquez-Morillas., A. 2018. Degradation of conventional and oxodegradable high density polyethylene in tropical aqueous and outdoor environments, Rev. Int. Contam
Ambient., 34(1): 137-147. doi: 10.20937/RICA. 2018.34.01.12.

ASTM D 2487-06. 2006. Standard Practice for Classification of Soils for Engineering Purposes (Unified Soil Classification System), ASTM Internasional, United States. 12pp.

Atwater, J. F. \& Lawrence, G. A. 2010. Power potential of a split tidal channel. Renew. Energ., 35:329332. doi: 10.1016/j.renene.2009.06.023

Babah, I.A., Deida, M.F., Blake, G. \& Froelich, D. 2012. Fresh water distribution problematic in Nouakchott. Proc. Eng., 33:321-329. doi: 10.1016/j.proeng.2012.01.1210.

Babah, I.A., Froelich, D., Deida, M.F. \& Blake, G. 2015. Evolution of the fresh water distribution in Nouakchott after the commissioning of the Aftout Es Saheli project. Desalinat. Water Treat., 57(13): 5932-5945. doi: 10.1080/19443994. 2015.1049957.

Badan Pusat Statistik BPS. 2020. Kota Tidore Kepulauan Dalam Angka (Tidore Kepulauan Municipality in Figures 2020). Badan Pusat Statistik Kota Tidore Kepulauan, 165p.

Badan Pusat Statistik BPS. 2019. Kecamatan Tidore Utara Dalam Angka 2019. Badan Pusat Statistik Kota Tidore Kepulauan, 77p.

Carneiro, D., Powell, S., Timmins, D. \& Bruzzo, P. 2013. Reassessment of Dynamically Stable Pipelines Accounting for Potential Clashing With New Assets. In ASME 32nd Int. Conf. Ocean, Offshore Arctic Eng. OMAE2013-10604. p:1-9.

Cheng, L., An, H., Draper, S. \& White, D. 2016. Effect of wave boundary layer on hydrodynamic forces on small diameter pipelines. Ocean Eng., 125:2630. doi: 10.1016/j.oceaneng.2016.07. 016.

Da Costa, J.P., Nunes., A.R., Santos, P.S.M., Girão, A.V., Duarte, A.C. \& Rocha-Santos, T. 2018. Degradation of polyethylene microplastics in seawater: Insights into the environmental degradation of polymers. J. Environ. Sci. Health, A, 53(9): 866-875. doi: 10.1080/10934529. 2018.1455381

Danish Hydraulic Institute [DHI]. 2012a. MIKE 21 Flow Model FM Hydrodynamic Module Scientific Documentation. DHI. 58p.

Danish Hydraulic Institute [DHI]. 2012b. MIKE 21 Spectral Waves FM Spectral Wave Module Scientific Documentation, DHI. 66p. 
de Kok, J.M. 2002. The influence of fresh water distribution on SPM transport in the Dutch coastal zone. Fine Sedimen. Dyn. Mar. Environ., 58:563-576.

DNV. 2017. DNV RP F105 Free Spanning Pipelines. Det Norske Veritas, 138p.

DNV. 2013. DNV OS F101 Submarine Pipeline Systems. Det Norske Veritas, 240p.

DNV. 1993. Rules for Submarine Pipelines. Det Norske Veritas, 153p.

DNV. 1988. RP F305 On-bottom Stability Design of Submarine Pipelines. Det Norske Veritas, 41p.

Foda, M.A. 1985. Pipeline breakout from seafloor under wave action. App. Ocean Res., 7(2): 7984. doi: 10.1016/0141-1187(85)90037-9.

Foda, M. A., Chang, J. Y. H. \& Law, A. W. K. 1990. Wave-induced break-out of half-buried marine pipes. J. Waterw. Port Coast. Ocean Eng., 116(2): 267-286. doi: 10.1061/(ASCE)0733950X(1990)116:2(267).

Hale, J.R., Lammert, W.F. \& Jacobsen, V. 1989. Improved basis for static stability analysis and design of marine pipelines. Proc. 22nd Offshore Technol. Conf. p: 171-180. doi: 10.4043/6059MS.

Hunt, E. M., Earl, P., Baraky, M., Kelly, T., Allen, B. 2017. MIC resistant HDPE lining for seawater applications, Corrosion, National Association of Corrosion Engineers (NACE International), 9776 : 26-30.

Mu, S., He, Y., He, Z., \& Su, B. 2015. Response of Fresh Water Distributions on Abrupt Changes of Topography in the Pearl River Networks of China,
MATEC Web of Conferences. EDP Sciences. 25: 7p. doi: 10.1051/matec conf/20152501004.

Novico, F., Astawa, I. N., Sinaga, A., \& Ali, A. 2015. Seafloor Morphology Influence on Current Condition in a Sunda Strait Bridge Project Using Numerical Model. Bull. Mar. Geol., 30(2): 55-66. doi: 10.32693/bomg.30.3.3015.75

Padman, L. 2005. Tide Model Driver (TMD) Manual. Arctic. 1-13pp.

Ross, D.A. 1995. Introduction to Oceanography. New York, NY: HarperCollins. pp. 236-242.

Sujarwanto. 2019. The Development of port in the Island Group Region: Case Study on Port of Rum in Tidore. J. Penelitian Transportasi Laut. 21: 51-60

Sumich, J.L. 1996. An Introduction to the Biology of Marine Life, sixth edition. Dubuque, IA: Wm. C. Brown. pp. 30-35.

Thurman, H.V. 1994. Introductory Oceanography, seventh edition. New York, NY: Macmillan. pp. 252-276.

Trechet, A.H. 2004. Morrison's Equation. Hydrodynamics for Ocean Engineers, 9pp.

United States Army Corps of Engineers [USACE]. 2002. Coastal Engineering Manual. Engineer Manual 1110-2-1100, United States Army Corps of Engineers, Washington, D.C.

Wu, H., Wang, X., Wang, B., Bai, Y. \& Wang, P., 2017. Evaluation of tidal stream energy and its impact on surrounding dynamics in the Eastern Region of Pingtan Island, China. Chin. J. Oceanol. Limnol., 35:1319-1328 doi: 10.1007/s00343017-0187-z 